\title{
Renal tubular proteinuria and microalbuminuria in diabetic patients
}

\author{
D M GIBB,${ }^{*} \mathrm{P}$ A TOMLINSON,$\dagger \mathrm{N}$ R DALTON, $\uparrow \mathrm{C}$ TURNER,$\dagger \mathrm{V}$ SHAH,$*$ \\ AND T M BARRATT* \\ Department of *Paediatric Nephrology, Institute of Child Health, London, and †Department of Paediatrics, \\ United Medical and Dental Schools of Guy's and St Thomas's Hospitals, London
}

SUMMARY The urinary extraction of albumin, retinol binding protein, and N-acetyl- $\beta$-Dglucosaminidase were studied in 60 children with insulin dependent diabetes mellitus and in 45 normal children to find out whether the renal tubules played a part in causing the early increase in urinary excretion of albumin that occurs in diabetes mellitus. Two overnight urine samples were collected and the protein excretion measured and expressed as the geometric mean of the protein to creatinine ratio (urinary albumin:creatinine ratio, urinary retinol binding protein:creatinine ratio, and urinary $\mathrm{N}$-acetyl- $\beta$-D-glucosaminidase:creatinine ratio, respectively). The excretion of all three proteins was significantly higher in the diabetic children with $15(25 \%)$ of urinary albumin:creatinine ratio, $16(27 \%)$ of urinary retinol binding protein:creatinine ratio, and $43(72 \%)$ of urinary $\mathrm{N}$-acetyl- $\beta$-D-glucosaminidase:creatinine ratio values being above the normal range. Significant correlations were observed between urinary albumin:creatinine ratio and urinary retinol binding protein:creatinine ratio, urinary albumin:creatinine ratio and urinary $\mathrm{N}$-acetyl- $\beta$-D-glucosaminidase:creatinine ratio, and urinary retinol binding protein:creatinine ratio and urinary $\mathrm{N}$-acetyl- $\beta$-D-glucosaminidase:creatinine ratio. There were also significant correlations between glycated haemoglobin $1 c\left(\mathrm{HbA}_{1 \mathrm{c}}\right)$ and these proteins, especially $\mathrm{N}$-acetyl- $\beta$ D-glucosaminidase. No correlations were observed with the fractional excretion of sodium, flow rate of urine, glomerular filtration rate, or blood pressure.

These data show that tubular abnormalities are present early in the course of insulin dependent diabetes mellitus and suggest that the early increase in urinary excretion of albumin may be at least partly tubular in origin, and that glycaemic control may influence this aspect of proximal tubular function.

Raised urinary excretion of albumin has been reported in $10-20 \%$ of children with insulin dependent diabetes mellitus. ${ }^{1-4}$ The importance of this remains unclear, however, and the finding of a high within individual variability of urinary excretion of albumin in both normal and diabetic children, ${ }^{5}$ and a possible association with the degree of immediate metabolic control in the diabetics, increases the problems of understanding its pathogenesis.

The excessive excretion of protein that characterises overt diabetic nephropathy is generally thought to be caused by increased glomerular permeability to protein, and it has been assumed that the variably raised urinary excretion of albumin that occurs early in diabetes is caused by a milder degree of the same pathogenic mechanism. ${ }^{67}$ The reasons for this assumption include the fact that glomerular filtration rate is raised early in the course of insulin dependent diabetes mellitus,$^{89}$ the fact that antihypertensive drugs decrease urinary excretion of albumin in both diabetics ${ }^{10}$ and patients with essential hypertension, ${ }^{11}$ and the morphological alterations in the structure and biochemistry of the diabetic glomerular basement membrane early in the course of the disease..$^{12} 13$

This interpretation of the early rise in the urinary excretion of albumin depends on the assumption that tubular fractional reabsorption of filtered albumin is unchanged. The presence of low molecular weight proteinuria undermines that assumption because it is caused by tubular dysfunction that might also impair the reabsorption of albumin. ${ }^{14}$

Urinary $\beta_{2}$ microglobulin is the principal low molecular weight protein that has been investigated 
in diabetic nephropathy. Results have been conflicting but the general conclusions were that although there may be an acute increase in $\beta_{2}$ microglobin excretion in poorly controlled diabetes, tubular impairment is important only in more advanced disease. ${ }^{15-18}$

Raised urinary excretion of retinol binding protein and $\mathrm{N}$-acetyl- $\beta$-D-glucosaminidase have been noted in association with damage to the renal tubules. ${ }^{19}$ Urinary excretion of retinol binding protein (a low molecular weight protein) correlates with that of $\beta_{2}$ microglobin in renal disease, ${ }^{20}$ and recently was found to be raised in $15 \%$ of diabetic adults even without microalbuminuria. ${ }^{21} \mathrm{~N}$-acetyl- $\beta$-D-glucosaminidase (a lysosomal enzyme originating from the proximal renal tubule cell) is not filtered by the glomerulus, but is liberated into the tubular lumen with proximal tubular damage. Increased levels in the urine have been reported in diabetic children both with and without evidence of nephropathy. ${ }^{22}$

The aims of this study were firstly to investigate the urinary excretion of albumin, retinol binding protein, $\mathrm{N}$-acetyl- $\beta$-D-glucosaminidase, and $\beta_{2}$ microglobin, and the associations among these proteins in the urine of normal and diabetic children, and secondly to investigate the association between glomerular haemodynamics and the excretion of these proteins. Thirdly we examined the associations between urinary excretion of these proteins and other measurements of tubular function and metabolic control.

\section{Patients and methods}

Sixty children and adolescents attending the diabetic clinics at the Hospital for Sick Children were investigated. Their mean age was 13.1 years (range 4.5-19) and the mean duration of their diabetes was seven years (range six months to $161 / 2$ years); 16 of the children were prepubertal, 17 in early puberty, and 27 in late puberty; there were 27 boys and 33 girls. None had evidence of urinary infection at the time of study. Concentrations of proteins in the urine were measured in all children as was the blood pressure; measurement of glomerular filtration rate was carried out in 44 .

Excretion of proteins in the urine was investigated in 45 normal children, mean age 13.3 years (range 4-8-17). Control subjects for the studies of glomerular filtration rate comprised 15 normal adolescents and young adults with a mean age of 24.9 years (range 17-33) recruited from hospital staff and friends. The study was approved by the ethical committee of the Hospital for Sick Children.

Concentrations of albumin in the urine were measured by radioimmunoassay using a commercially available kit (Diagnostic Products Corporation); concentrations of retinol binding protein in the urine by an enzyme linked immunosorbent assay (ELISA) using rabbit antisera (Dako Ltd) ${ }^{23}$ and the activity of $\mathrm{N}$-acetyl- $\beta$-D-glucosaminidase in the urine by an automated colourimetric method using p-Nitrophenyl-N-acetyl- $\beta$-D-glucosamide (Sigma Chemical Co) as substrate. ${ }^{24}$ Urinary creatinine was measured by the Jaffe reaction. Excretion of protein in the urine was expressed as the geometric mean of the ratio of the protein concentration to that of creatinine in two consecutive overnight urine samples (urinary albumin:creatinine ratio in $\mathrm{mg} / \mathrm{mmol}$; urinary retinol binding protein:creatinine ratio in $\mu \mathrm{g} / \mathrm{mmol}$; and urinary $\mathrm{N}$-acetyl- $\beta$-Dglucosaminidase:creatinine ratio in $\mu \mathrm{mol}$ of p-nitrophenylic acid/hour/mmol). $\quad \beta_{2}$ microglobin was measured by an ELISA in single random morning urine specimens collected during water diuresis placed immediately in sodium bicarbonate, and then frozen at $-20^{\circ} \mathrm{C}$. Results were also expressed as a concentration ratio with respect to creatinine (urinary $\beta_{2}$ microglobulin:creatinine ratio, in $\mu \mathrm{g} / \mathrm{mmol}$ ), and these are given only for the diabetic children.

Glomerular filtration rate was measured during a constant infusion of ${ }^{51}$ chromium edetic acid under conditions of water diuresis with spontaneous voiding of urine ${ }^{25}$ Estimates of glomerular filtration rate were rejected if one or more individual clearances differed from the mean by more than $15 \%$. Acceptable estimates of glomerular filtration rate were obtained in 41 of the 44 children studied.

Blood pressure was measured using a random zero sphigmomanometer with the child seated. Results were expressed as standard deviation scores standardised against the 1987 Task Force data for blood pressure in normal children. ${ }^{26}$

Urinary sodium and plasma sodium concentrations were measured by flame photometry. Fractional excretion of sodium measured in the diabetic children was calculated from the formula: fractional excretion of sodium $=$ (urinary sodium/plasma sodium concentration)/(urinary creatinine/plasma creatinine concentration). In addition, as plasma sodium and creatinine concentrations were not measured in the normal children, the urinary excretion rates of sodium were compared in normal and diabetic children ( $\mathrm{mmol} /$ minute).

Glycated haemoglobin 1c $\left(\mathrm{HbA}_{1 \mathrm{c}}\right)$ was measured by electrophoresis, the normal range being $5-8 \%$.

Computation and statistical analysis were done using the Statistical Analysis System (SAS Institute Inc). Urinary albumin:creatinine ratio, urinary retinol binding protein:creatinine ratio, urinary $\mathrm{N}$ acetyl- $\beta$-D-glucosaminidase:creatinine ratio and 
urinary $\beta_{2}$ microglobulin:creatinine ratio were shown to be logarithmically normally distributed by normal order plots. ${ }^{5}$ Results were therefore transformed logarithmically before analysis. The unpaired Student's $t$ test, linear regression by the least square method, and multiple regression, were used to analyse the data.

\section{Results}

Geometric means (range, $2 \mathrm{SD}$ ) for urinary albumin:creatinine ratio, urinary retinol binding protein:creatinine ratios, and urinary $\mathrm{N}$-acetyl- $\beta$-Dglucosaminidase:creatinine ratios were significantly higher in diabetic compared with normal children (table 1). In the diabetic children, $15(25 \%)$ of urinary albumin:creatinine ratio, $16(27 \%)$ of urinary retinol binding protein:creatinine ratio, and 43 $(72 \%)$ of urinary $\mathrm{N}$-acetyl- $\beta$-D-glucosaminidase: creatinine ratio values were more than two standard deviations above the mean for the normal children.

Mean (SD) glomerular filtration rate in the diabetic children was 129 (19) $\mathrm{ml} /$ minute $/ 1.73 \mathrm{~m}^{2}$ surface area, which was significantly greater than $109(13)(\mathrm{p}<0.001)$ in the control subjects (table 2), and $(30 \%)$ had values about the normal range. The mean diastolic (but not systolic) blood pressure standard deviation score was significantly raised in the diabetic children, as was the urinary flow rate but not the sodium excretion (table 2).
Significant positive correlations were found between urinary albumin:creatinine ratio and urinary retinol binding creatinine:creatinine ratio $(r=0.67, p<0.0001)$, urinary albumin:creatinine ratio and urinary $\mathrm{N}$-acetyl- $\beta$-D-glucosaminidase:creatinine ratio $(r=0.55, p<0 \cdot 0001)$, and urinary retinol binding creatinine:creatinine ratio and urinary $\mathrm{N}$ acetyl- $\beta$-D-glucosaminidase:creatinine ratio $(r=0 \cdot 70$, $\mathrm{p}<0.0001$ ) (figs 1,2 , and 3 ). In 39 of the random

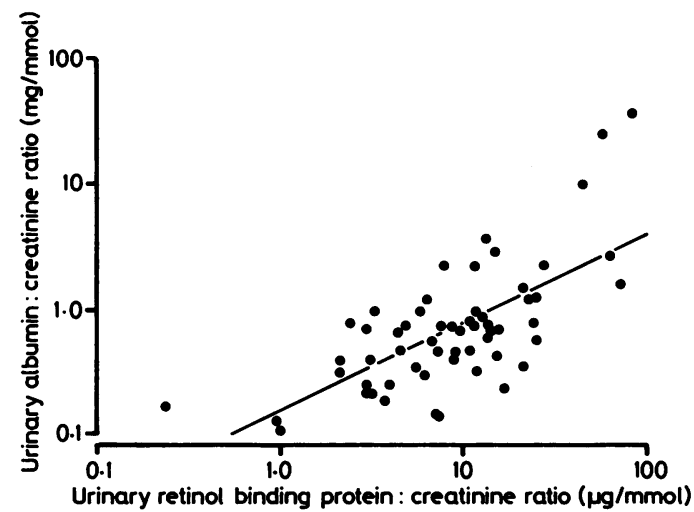

Fig 1 Scattergram of urinary albumin:creatinine ratio and urinary retinol binding protein:creatinine ratio (data transformed logarithmically). Correlation coefficient is $\mathbf{0 . 6 7}$ $(p<0.0001)$.

Table 1 Geometric means (ranges-2 SD) for measurements of protein excretion in children with insulin dependent diabetes mellitus and normal children

\begin{tabular}{|c|c|c|c|}
\hline & $\begin{array}{l}\text { Diabetic } \\
\text { children } \\
(n=60)\end{array}$ & $\begin{array}{l}\text { Normal } \\
\text { children } \\
(n=45)\end{array}$ & $\begin{array}{l}p \\
\text { Value }\end{array}$ \\
\hline Urinary albumin:creatinine ratio $(\mathrm{mg} / \mathrm{mmol})$ & $0 \cdot 72(0.08-6 \cdot 9)$ & $0.41(0 \cdot 14-1 \cdot 17)$ & $<0.001$ \\
\hline Urinary retinol binding protein:creatinine ratio $(\mu \mathrm{g} / \mathrm{mmol})$ & $8 \cdot 5(1 \cdot 0-74 \cdot 0)$ & $3 \cdot 8(1 \cdot 0-15 \cdot 1)$ & $<0.001$ \\
\hline $\begin{array}{l}\mathrm{N} \text {-acetyl- } \beta \text {-D-glucosaminidase:creatinine ratio } \\
(\mu \mathrm{mol} \text { p-nitrophenylic acid/hour } \mathrm{mmol})\end{array}$ & $39 \cdot 8(5 \cdot 5-238)$ & $6 \cdot 8(1 \cdot 8-25 \cdot 0)$ & $<0.001$ \\
\hline
\end{tabular}

Table 2 Mean (SD) urine flow rate, fractional excretion of sodium, sodium excretion rate, blood pressure standard deviation scores, glomerular filtration rate in children with insulin dependent diabetes mellitus and normal children

\begin{tabular}{|c|c|c|c|}
\hline & $\begin{array}{l}\text { Diabetic } \\
\text { children } \\
(n=60)\end{array}$ & $\begin{array}{l}\text { Normal } \\
\text { children } \\
(n=45)\end{array}$ & $\begin{array}{l}p \\
\text { Value }\end{array}$ \\
\hline Urinary flow ( $\mathrm{ml} / \mathrm{minute})$ & $0.77(0.44)$ & $0.41(0 \cdot 23)$ & $<0.001$ \\
\hline Fractional excretion of sodium (\%) & $0.53(0.35)$ & Not measured & \\
\hline Sodium excretion rate $(\mathrm{mmol} / \mathrm{minute})$ & $0.06(0.04)$ & $0.05(0.03)$ & NS \\
\hline Systolic blood pressure standard deviation score & $+0 \cdot 15(0.65)$ & Not measured & NS $\ddagger$ \\
\hline Diastolic blood pressure standard deviation score & $+0.51(0 \cdot 82)$ & Not measured & $<0 \cdot 01 \ddagger$ \\
\hline Glomerular filtration rate $\left(\mathrm{ml} / \mathrm{minute} / 1.73 \mathrm{~m}^{2}\right.$ surface area) & $129(19)^{*}$ & $109(13) \dagger$ & $<0.001$ \\
\hline
\end{tabular}

${ }^{*} n=41 ; \nmid n=15$; $\ddagger$ compared with the 1987 Task Force data for blood pressure in normal children. ${ }^{26}$ 
132 Gibb, Tomlinson, Dalton, Turner, Shah, and Barratt

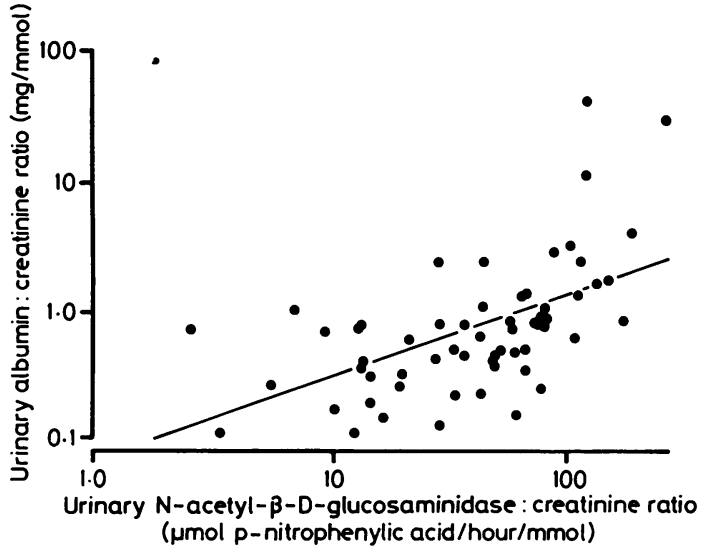

Fig 2 Scattergram of urinary albumin:creatinine ratio and urinary $N$-acetyl- $\beta$ - $D$-glucosaminidase:creatinine ratio (data transformed logarithmically). Correlation coefficient is $0.55(p<0.0001)$.

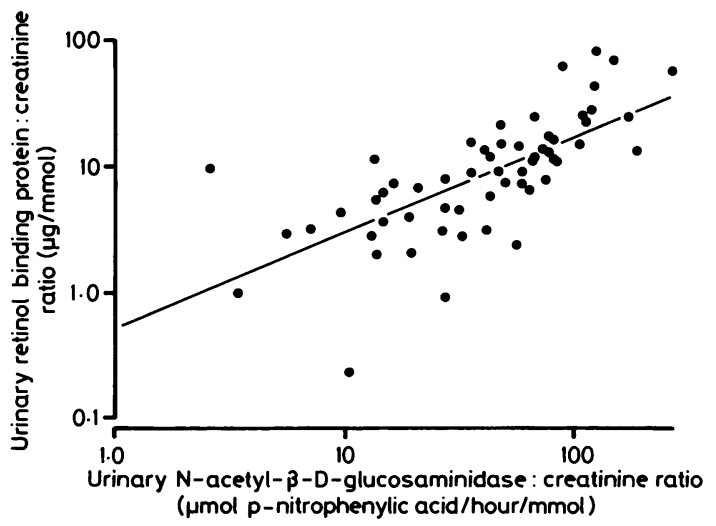

Fig 3 Scattergram of urinary retinol binding protein:creatinine ratio and urinary $N$-acetyl- $\beta$-D-glucosaminidase: creatinine ratio (data transformed logarithmically). Correlation coefficient is $0 \cdot 70$ $(p<0.0001)$. urine samples from the diabetic children, the $\mathrm{pH}$ was between 6.5 and 9.5 . In these samples, the correlation between urinary $\beta_{2}$ microglobulin: creatinine ratio and urinary retinol binding protein: creatinine ratio was highly significant $(r=0 \cdot 68$, $\mathrm{p}<0 \cdot 0001)$.

Concentrations of all three proteins correlated weakly but significantly with age in diabetic but not in normal children, and there was a weak correlation between duration of disease and urinary $\mathrm{N}$-acetyl- $\beta$ D-glucosaminidase:creatinine ratio but not with the other proteins (table 3 ). In the diabetic children, $\mathrm{HbA}_{1 \mathrm{c}}$ concentrations correlated with all three proteins (table 3 ). As age correlated with both $\mathrm{HbA}_{1 \mathrm{c}}$ concentration and excretion of the proteins, this was held constant by multiple regression analysis; the association between protein excretion and $\mathrm{HbA}_{\mathrm{lc}}$ concentration remained significant for all three proteins.

When the association between urinary albumin: creatinine ratio and glomerular filtration rate was studied it was found that although there was no significant correlation between them $(r=0 \cdot 29$, NS), seven of 10 diabetic children who had urinary albumin:creatinine ratio above the the normal range also had glomerular filtration rate above the normal range $\left(\mathrm{p}<0.001, \chi^{2}\right)$. There was no association between urinary retinol binding protein:creatinine ratio or urinary $\mathrm{N}$-acetyl- $\beta$-D-glucosaminidase: creatinine ratio and glomerular filtration rate, or between blood pressure and urinary excretion of any of the proteins. There was no correlation between urinary excretion of proteins and urinary flow rate or fractional excretion of sodium in either the diabetic or the normal children.

\section{Discussion}

We have found that children and adolescents with insulin dependent diabetes mellitus have significantly raised urinary excretion of albumin, retinol binding protein, and $\mathrm{N}$-acetyl- $\beta$-D-glucosaminidase. The good correlation between the excretion of all three

Table 3 Correlation coefficients for relationships between urinary albumin:creatinine ratio, urinary retinol binding protein:creatinine ratio, urinary $N$-acetyl- $\beta-D$-glucosaminidase:creatinine ratio and age, duration of disease and mean $H b A_{1 c}$ concentration

\begin{tabular}{llll}
\hline & $\begin{array}{l}\text { Urinary } \\
\text { albumin:creatinine } \\
\text { ratio }\end{array}$ & $\begin{array}{l}\text { Urinary retinol } \\
\text { binding protein:creatinine } \\
\text { ratio }\end{array}$ & $\begin{array}{l}\text { Urinary } \\
N \text {-acetyl- } \beta \text {-D-glucosaminidase: } \\
\text { creatinine ratio }\end{array}$ \\
\hline Mean age & $0 \cdot 35^{*}$ & $0 \cdot 35^{*}$ & $0 \cdot 50^{* * *}$ \\
Mean duration of disease & $0 \cdot 08$ & $0 \cdot 27$ & $0 \cdot 39^{* *}$ \\
Mean $\mathrm{HbA}_{1 \mathrm{c}}$ concentration & $0 \cdot 34^{*}$ & $0 \cdot 36^{*}$ & $0 \cdot 57^{* * *}$ \\
\hline
\end{tabular}

${ }^{*} \mathrm{p}<0 \cdot 01,{ }^{* *} \mathrm{p}<0 \cdot 001,{ }^{* * *} \mathrm{p}<0 \cdot 0001$. 
proteins in the diabetic children suggests that the increased urinary excretion of albumin may, at least in part, be caused by proximal tubular dysfunction.

The main evidence that the early increase in urinary excretion of albumin in diabetes is of glomerular origin is that it is not paralleled by an increase in tubular proteinuria, particularly $\beta_{2}$ microglobin. ${ }^{7}$ Several studies in adults with insulin dependent diabetes mellitus have shown normal 24 hour urinary excretion of this protein ${ }^{15-18}$ and reported abnormalities have usually been associated with ketoacidosis ${ }^{27}$ poor metabolic control ${ }^{28}$ or exercise.$^{29}$ One reason for these conflicting results is likely to be the instability of $\beta_{2}$ microglobin in acid or extremely alkaline urine, and in the presence of pyuria, making it an unsuitable marker for assessing tubular dysfunction unless the patient is given an oral alkali before and during the period of urine collection. ${ }^{30}$ An alternative method (which we undertook in this study) is to collect urine samples during water diuresis and immediately place them in sodium bicarbonate. We confirmed the results of Bernard et al ${ }^{20}$ who also found a good correlation between excretion of $\beta_{2}$ microglobin and retinol binding protein in random samples of urine from diabetic children.

Few other low molecular weight proteins have been investigated in diabetes. Raised concentrations of retinol binding protein have been reported in diabetic adults, ${ }^{21}$ and Walton et al recently found raised urinary excretion of $\alpha 1$ microglobulin and $x$ light chains in diabetic children, and good correlations between them. ${ }^{31}$ Contrary to our findings, they found no increase in urinary excretion of albumin in diabetic compared with normal children. However, although the amounts of albumin in the urine which they found in the diabetic children were similar to ours, the amounts in their normal children were higher than those found by most investigators (including ourselves). ${ }^{125}$ In addition, the mean age of and duration of disease in the diabetic children that they studied were significantly lower than ours.

The correlation between the concentration of $\mathrm{HbA}_{1 \mathrm{c}}$ and excretion of the three proteins raises the possibility that poor glycaemic control may be important. The good correlation reported by Watanabe et $a l^{22}$ between $\mathrm{N}$-acetyl- $\beta$-D-glucosaminidase activity and urinary glucose concentration would support the experimental evidence that secretion of the enzyme by cultured fibroblasts correlates with the amount of glucose metabolised by the cells. ${ }^{32}$ Glycosuria has been associated with alterations in tubular transport of sodium, calcium, and phosphate, ${ }^{33}$ and could alter the transport of low molecular weight proteins such as retinol binding protein. Furthermore, competition has recently been reported between uptake of albumin and $\beta_{2}$ microglobin in rats, suggesting that tubular reabsorption of small and large molecules may not take place through distinct pathways as is currently thought. ${ }^{34}$

Although the flow rate of urine was increased in the diabetic children, we found no correlation with urinary excretion of protein. This is in accordance with the experimental work that has shown that reabsorption of phosphate, which is also decreased in diabetes, ${ }^{35}$ is linked to absorption of glucose directly and is not a non-specific osmotic intraluminal effect. No change in reabsorption of phosphate is observed if mannitol is substituted for glucose. ${ }^{35}$

We found no correlations between excretion of the proteins and fractional excretion of sodium or the excretion rate of sodium; this was also reported by Ditzel et al..$^{33} \mathrm{We}$ also found no correlations between glomerular filtration rate or blood pressure, or excretion of either retinol binding protein or $\mathrm{N}$-acetyl- $\beta$-D-glucosaminidase. Although no linear correlation was found, however, a threshold association does exist between urinary albumin:creatinine ratio and glomerular filtration rate, as we have reported previously. ${ }^{25}$

In conclusion, our data demonstrating increased excretion of retinol binding protein and $\mathrm{N}$-acetyl- $\beta$ D-glucosaminidase in association with positive correlations with urinary albumin:creatinine ratio in children with insulin dependent diabetes mellitus indicate that renal tubular function is impaired early in the course of the disease, and may be at least partly the cause of the early abnormal urinary excretion of albumin. Whether the tubular abnormalities are purely functional requires further study of the mechanisms of tubular absorption in both normal and diabetic subjects.

We thank Dr D Grant and Dr M Savage for permitting the diabetic children at the Hospital for Sick Children to take part in the study, Professor M Preece for permission to obtain urine samples from the children of Holywood School, Chard, Somerset, Ms J Jones and Dr D Dunger for help with collecting urine samples, and $\mathrm{Mr}$ W Wilson for measuring urinary creatinine concentrations and for his help with measuring glomerular filtration rates.

This project was supported by grants from Boehringer Ingelheim, the Kidney Rescarch Aid Fund, and the Children Nationwide Medical Research Fund.

\section{References}

${ }^{1}$ Davies AG, Price DA, Postlethwaite RJ, Addison GM, Burn JL, Fielding BA. Renal function in diabetes mellitus. Arch Dis Child 1985;60:299-304.

2 Mathiesen ER, Saurbrey N, Hommel E, Parving H-H. Prevalence of microalbuminuria in children with insulin-dependent diabetes. Acta Endocrinol 1986;112(suppl 275): 14-22.

${ }^{3}$ Ellis D, Becker DJ, Daneman D, Lobes L, Drash AL. Proteinuria in children with insulin-dependent diabetes: rela- 
tionship to duration of disease, metabolic control, and retinal changes. J Pediatr 1983;102:673-80.

* Mogensen CE. Urinary albumin excretion in early and longterm juvenile diabetes. Scand J Clin Lab Invest 1971;28:183-93.

5 Gibb DM, Preece M. Shah V, Wilson W, Barratt TM. Variability of urine albumin excretion in normal and diabetic children. Paediatric Nephrology (in press).

${ }^{6}$ Mogensen CE. Microalbuminuria as a predictor of clinical diabetic nephropathy. 1987:31:673-89.

7 Viberti GC, Keen H. The patterns of proteinuria in diabetes mellitus. Diabetes 1984;33:686-92.

${ }^{8}$ Brochner-Mortensen J, Ditzel J, Mogensen CE, Rodbro P. Microvascular permeability to albumin and glomerular filtration rate in diabetic and normal children. Diabetologia 1979;16: $307-11$.

${ }^{9}$ Berg UB, Thalme B. Early renal functional changes in children with insulin-dependent diabetes mellitus-their relation to metabolic control. Int J Pediatr Nephrol 1984;5:15-21.

10 Parving H-H, Smidt UM. Hypotensive therapy reduces microvascular albumin leakage in insulin-dependent diabetic patients with nephropathy. Diabetic Medicine 1986;3:312-5.

$"$ Christensen CK. Rapidly reversible albumin and beta-2microglobulin hyperexcretion in recent severe essential hypertension. J Hypertens 1983:1:45-51.

12 Williamson JR, Kilo C. Basement membrane thickening and diabetic microangiopathy. Diabetes 1976;25:925-7.

1.3 Beisswenger PJ. Glomerular basement membrane: biosynthesis and chemical composition in the streptozotocin diabetic rat. $J$ Clin Invest 1976:58:844-52.

it Abrass CK. Diabetic proteinuria: glomerular or tubular in origin? Am J Nephrol 1984:4:337-46.

15 Viberti GC, Mackintosh D. Bilous RW, et al. Proteinuria in diabetes mellitus: role of spontaneous and experimental variation of glycaemia. Kidney Int 1982;21:714-20.

${ }^{16}$ Mogensen CE. Renal function changes in diabetes. Diabetes 1976;25:872-9.

17 Mathiesen ER, Oxenboll B, Johansen K, et al. Incipient nephropathy in type 1 (insulin-dependent) diabetes. Diabetologia 1984:26:406-10.

18 Deckert T, Feldt-Rasmussen B, Djurup R. Deckert M. Glomcrular size and charge selectivity in insulin-dependent diabetes mellitus. Kidney Int 1988;33:100-6.

19) Kunin CM, Chesney RW, Craig WA, England AC, DeAngelis C. Enzymuria as a marker of renal injury and disease: studies of $\mathrm{N}$-acetyl- $\beta$-glucosaminidase in the general population and in patients with renal disease. Pediatrics 1978:62:751.

21) Bernard AM, Moreau D. Lauwerys R. Comparison of retinolbinding protein and $\beta_{2}$-microglobulin determination in urine for the carly detection of tubular proteinuria. Clin Chim Acta 1982:126:1-7.

2 Rowe DJF, Anthony F, Polak A, Shaw K, Ward CD. Retinol binding protein as a small molecular weight marker of renal tubular function in diabetes mellitus. Ann Clin Biochem 1987:24:477-82.
22 Watanabe Y, Nunoi K, Maki Y, Nakamura Y, Fujishima M. Contribution of glycaemic control to the levels of $N$-acetyl- $\beta$-Dglucosaminidase and serum NAG in type 1 (insulin-dependent) diabetes mellitus without macroalbuminuria. Clin Nephrol 1987;28:227-31.

23 Topping MD, Forster HW, Dolman C, Luczynska CM, Bernard AM. Measurement of urinary retinol-binding protein by enzyme-linked immunosorbent assay and its application to the detection of tubular proteinuria. Clin Chem 1986;32:1863-6.

${ }^{24}$ Marulin D. Rapid colorimetric assay of B-D-galactosidase and $\mathrm{N}$-acetyl- $\beta$-D-glucosaminidase in human urine. Clin Chim Acto 1976;73:453-61.

25 Gibb DM, Dunger DB, Levin M, Shah V, Smith C, Barratt TM. Early markers of the renal complications of insulin-dependent diabetes mellitus in children. Arch Dis Child (in press).

26 National Heart, Lung and Blood Institute. Bethesda, Maryland. Report of the second task force on blood pressure control in children, 1987. Pediatrics 1987;79:1-25.

${ }_{27}$ Miltenyi M, Korner A. Tulassay T, Szabo A. Tubular dysfunction in type 1 diabetes mellitus. Arch Dis Child 1985;60:929-31.

${ }^{28}$ Parving H-H, Noer I, Deckert T, et al. The effect of metabolic regulation on microvascular permeability to small and large molecules in short-term juvenile diabetes. Diabetologia 1976; 12:161-6.

${ }^{29}$ Mogensen CE. Renal function changes in diabetes. Diabetes 1976;25:872-9.

31) Schardijn GHC, Statius van Eps LW. $\beta_{2}$-microglobulin: its significance in the evaluation of renal function. Kidney Int 1987:32:635-41.

31 Walton C, Bodansky HJ. Wales JK, Forbes MA, Cooper EH. Tubular dysfunction and microalbuminuria in insulin dependent diabetes. Arch Dis Child 1988;63:244-9.

32 Hultberg B, Isaksson A. Kjellström T. The effects of glucose and insulin on beta-hexosaminidase in cultured fibroblasts in diabetic and non-diabetic subjects. Ann Clin Biochem 1985;22: 133-6.

33 Ditzel J, Brochner-Mortensen, J, Kawahara R. Dysfunction of tubular phosphate reabsorption related to glomerular filtration and blood glucose control in diabetic children. Diabetologia 1982:23:406-10.

${ }^{34}$ Bernard A, Viau C, Ouled A, Lauwerys R. Competition between low- and high-molecular-weight proteins for renal tubular uptake. Nephron 1987:45:115-8.

${ }^{35}$ Fox M, Thur S, Rosenberg L, Segal S. Impaired renal tubular renal function induced by sugar infusion in man. $J$ Clin Endocrinol Metab 1964:24:1318-27.

Correspondence to Dr D Gibb, Department of Paediatric Nephrology, Institute of Child Health, 30 Guilford Street, London WCIN 1EH.

Accepted 30 June 1988 